\title{
Natural resources revenues, agriculture development and urbanization in African countries
}

\section{Evidence from a static and dynamic panel data}

Jamal Azizı*

DOI: $10.30682 / \mathrm{nm} 2003 \mathrm{~b}$

JEL codes: B23, C23, O15, P25, Q10

\begin{abstract}
This paper analyzes the mechanism through which natural resource abundance leads to a poor agricultural performance and a rapid urbanization in African countries. We conducted a static and dynamic panel data analysis for a panel of 39 African countries during the period 2000-2013. Our findings show that natural resources rents have a negative impact on agricultural performance and a positive impact on food import dependency. In addition, the results show a significant positive impact of resource rents on rural-urban migration and on urbanization rate. We argue that these findings can be explained by the government choice to specialize in primary commodities to the detriment of the development of other productive sectors, especially agriculture. Because policy makers tend to invest resources rents in developing infrastructures, mostly in cities, this inevitably creates some pulling factors for rural population in search of a better life. Consequently, we observe a rapid urbanization associated with serious problems (expansion of urban slums, limited access to improved water and sanitations facilities) in many African countries, highly dependent on natural resource rents.
\end{abstract}

Keywords: Natural resources curse, Agriculture, Urbanization, Panel data, GMM.

\section{Introduction}

The possession of natural resources such as oil, natural gas, diamonds or other mineral deposits does not necessarily lead to economic growth. Many African countries such as Nigeria, Angola, Sudan, Algeria and Congo are classified as resource-rich countries with non-significant economic development, less democracy, a low per capita income and poor living standards. Richard Auty (1986) is apparently the first one who used the term "natural resources curse" to describe this puzzling phenomenon. Empirically, the most popular study by Sachs and Warner (1995) found a strong correlation between natural resources abundance and poor economic growth. Since then, abundant literature has evaluated the effects of natural resources on a wide range of economic, institutional and political performance indicators, and offered a variety of theories and explanations to this complicated

\footnotetext{
* Postdoctoral position at EIEA chair, Science and technological department, Mohammed VI Polytechnic University, Ben Guerir, Morocco.

Corresponding author: jamal.azizi@um6p.ma
} 
phenomenon. The purpose of this study is to propose new possible explications for the resource curse in African countries. The study seeks to answer the following questions: first, can oil and mineral resources abundance explain the agricultural poor performance? Second, is there a relationship between natural resources abundance and urbanization trends? Two main hypotheses are tested. The first one suggests that the abundance of oil and mineral resources allows policy makers to specialize in primary commodities and prevents the development of other productive sectors, especially agriculture. This would have a negative consequence on agricultural production, rural employment, food security and would therefore lead to an acceleration of rural-urban migration. The relation between resource revenues (i.e. export oil) and food security was tested in the literature. For instance, Djella et al. (2019) test the extent to which, in six countries within the Africa and Middle East areas, gas resources richness (oil-export) contribute to the food dependency in terms of food import and to the food insecurity (undernourishment). Using OLS and quantile regression, the authors shows the sizable and statistically significant impact of oil export on food import and undernourishment. The second hypothesis suggests that oil and mining revenues are mostly spent in cities in order to improve living conditions (housing, water, electricity, health, education, etc.). In general, this could have a positive effect on economic growth. However, the urbanization trend is accelerated by the migration of a rural population looking for jobs and a better life. This may explain the current situation of major African cities with considerable urban problems (slums, pollution, crime, overcrowding, informal sector, etc.). At this point, we note that the available empirical studies show no clear effect of urbanization on growth. The causal relationship between economic growth and urbanization remains unclear, according to the 2010 UN-HABITAT's report. ${ }^{1}$

This study differs from others on three points. First, we use the same framework to present two explanations (or channels) for the natural resources curse in African countries. We link natural resources abundance to the poor agricultural performance and the current urbanization situation. Second, our findings are derived from an empirical analysis based on a panel of 39 African countries. Therefore, the results can provide a global picture of the resource curse for the whole continent. Third, we conduct both static and dynamic panel regression models. The static specification allows the estimation of a country-specific effect while the dynamic specification captures the second round' effects and reduces the effects of unobserved or missing variables. This help us to better capture the complexity of the resource curse paradox.

The rest of the paper is organized as follows. Section 2 presents the literature review related to natural resources curse channels in Africa and the most used proxies for natural resources abundance or dependency measures. The analytical framework is introduced in Section 3. The next section displays a description of the selected variables, data sources and some statistical evidences. We discuss our empirical investigation in Section 5. Finally, we make concluding remarks in Section 6.

\section{Review of natural resources curse explanations in Africa}

The resource curse is a paradoxical phenomenon observed in countries with abundant natural resources, specifically non-renewable resources like oil and minerals tend not to perform as well economically as those without. The Sub Saharan Africa (SSA) region has become a classic case of the resource curse in the literature. Many countries in the region like the Democratic Republic of Congo (DRC), Chad, Mali, Liberia, Sierra Leone, Sudan and several others, are rich in natural resources, notably oil, minerals and precious metals, but are still classified as low-income economies. Only one country, Botswana has succeeded in becoming an upper middle-income country using its natural resources and has escaped the Resource Curse (Englebert, 2002; Sarraf and Jimanji, 2001; Iimi, 2006).

1 UN-HABITAT's report, Urban Trends: Urbanization and Economic Growth (2010). 
How could resources abundance be a curse? What could be the mechanism for this counter-intuitive relationship?

The literature proposes several theories to explain this phenomenon. Several authors (e.g. Frankel, 2010; Van der Ploeg, 2011; Torres et al., 2013; Badeeb et al., 2017) have conducted a very thorough literature review and summarized potential mechanisms for the resource curse. Broadly speaking, there are at least four lines of arguments: Dutch Disease, volatility in commodity prices, rent seeking/corruption and institutional quality. The first explanation based on the Dutch Disease suggests that the resource curse might occur when a boom in the resource sector causes a persistent appreciation of the real exchange rate and inflation. This appreciation makes non-resource commodities exports more expensive and imports cheaper and leads to a trade balance deficit in the short term. In the medium and long terms, this situation can create barriers to investments in non-resource tradable sectors and consequently curbs development (Sachs and Warner, 1995; 1997; 2001; Gylfason, 2001a; Papyrakis and Gerlagh, 2004). This negative effect is commonly called the "spending effect". In addition, the natural resources sector attracts capital and labor from other parts of the economy. As a result, the input production costs of other traditional export sectors such as manufacturing and agriculture increase. This resource reallocation is usually denominated "indirect-deindustrialization" (Corden and Neary, 1982; Corden, 1984) or "resource pull effect" (Humphreys et al., 2007). For African countries, both effects are reflected in the decline of the agriculture sector. Other explanations for the resource curse, often cited in the literature as symptoms of the Dutch Disease, are related to the disincentive for entrepreneurship (Sachs and Warner, 2001), the decrease in savings and physical investment (e.g., Gylfason, 2001a; Papyrakis and Gerlagh, 2007) and lower investment in education and human capital (e.g., Gylfason, 2001b; Birdsall et al., 2001; Bravo-Ortega and Gregorio,
2005). This might explain why one out of three young people in SSA region fail to complete primary school and need alternative pathways to acquire basic skills for employment (UNESCO, 2012). ${ }^{2}$

The second explanation suggests that the resource curse may operate because oil and mineral commodity prices are more volatile than the prices of other manufactured products. Volatility increases uncertainty in government revenues, and makes it difficult to conduct effective planning and therefore reduces economic growth (Davis and Tilton, 2005). This situation also explains the debt crisis observed in resource-rich countries during the 1980's (Van der Ploeg, 2011). In order to ensure debt repayment and economic restructuring, the IMF and the WB created the so-called Structural Adjustment Policies (SAPs) for a majority of African countries. Poor countries were forced to reduce spending on health, education and infrastructure, while debt repayment and budget balance became the priority.

The third explanation associates the resource curse with rent seeking behaviors and corruption (Auty 2001). According to Collier and Hoeffler (2005), rent-seeking occurs when "individuals or firms compete to obtain economic rents that arise when government restrictions are imposed" while corruption is defined, according to Kaufmann and Vicente (2011), as the abuse of public or private office, position, or power for private gain in contravention of established rules or norms. These two economic challenges are the principal reasons for underdevelopment in many African regimes (Coolidge and Rose-Ackerman 1999). In addition, Ross (2001) concludes that oil abundance hampers democracy. More recently, Arezki and Gylfason (2013) examined the impact of the interaction between resource rents and democracy and corruption for a panel of African economies. They found that large resource rents lead to more corruption, but that the effect is lower for more democratic countries. Finally, the literature shows evidence of

\footnotetext{
2 The tenth Education for All Global Monitoring Report, UNESCO (2012).
} 
the negative impact of resources abundance and the quality of institutions. For example, Mehlum et al. (2006) have demonstrated, using regression analysis that the resource curse is strongly present in countries with weak institutions but is barely present in countries with strong institutions. Other authors like Isham et al. (2005), Bulte et al. (2005), Robinson et al. (2006) and Collier (2010) conclude that natural resources abundance is a cause of poor institutional quality.

\subsection{Resource curse studies using panel data}

In order to test the resource curse for a panel of countries, the literature proposes different methodologies. Some authors use cross-sectional analysis while others use panel data analysis. In cross-sectional analysis, an equation is estimated for a number of countries at a specific point of time. The estimation does not incorporate any temporal dynamics. This method has been used by several authors (see Table 1). In this case, two problems can rise. The first one may stem from a potential endogeneity of resources abundance proxies with growth variables. The second lies in the control of all country-specific effects. In addition, cross-section estimation is more sensitive to omitted variables that may reflect country specific characteristics. Panel data seem to be a solution for these problems. Compared to cross-sectional data, the advantages of panel data lie in using information for both temporal and individual dimensions and it is possible to estimate the country-specific effects. This would reduce the effect of unobserved or omitted variables bias (see Manzano and Rigobon 2001 for comments and justification).

Regarding the results of cross sectional and panel data analysis, a relationship between resources abundance and economic growth might differ. Some authors find evidence of the resource curse while others do not. Based on Torres et al. (2013) and Zagozina (2014) surveys and several other studies, Table 1 summarizes recent cross sectional and panel studies on the resource curse and their main findings. The major outcomes presented in the table reflect the importance of choosing relevant resource abundance proxies. In the following section, we discuss different proxies used in the literature to measure this concept.

\subsection{Measures for non-renewable resource abundance}

The literature proposes a number of natural resources abundance or dependency proxies. There are at least four measures for natural resources abundance mostly used by authors (see Table 1): (i) Ratio of natural resources exports to gross domestic product (GDP), (ii) Share of natural resources exports in total exports, (iii) Ratio of mineral production to gross national product (GNP), and (iv) Rents from natural resources over GDP or per capita. Other proxies are used in the literature. For instance, Stijns (2005) measures natural resources abundance by the present value of mineral reserves and finds no correlation between this variable and economic growth. Lederman and Maloney (2008) use the Leamer index (natural resources net exports/labor force) and find no significant impact with respect to GDP per capita growth.

In this study, we use non-renewable resources rents to GDP, which we note "Rent", as a measure of natural resources abundance. We use GDP as a denominator to take into account the country size. As we hope to evaluate the impact of resource rent on agricultural performance, we include only minerals, oil and gas rents and exclude forestry and other agricultural resources rents to deal with a possible endogeneity problem. According to the World Bank, the rent for a given commodity is calculated as the difference between the price of this commodity and it average cost of production. The unit rent is multiplied by the physical quantity extracted and expressed as a share of GDP. The choice of this measure is justified by two reasons. First, the use of production or exports of natural resources tend to overestimate the abundance or dependence as no deduction of production cost is made. Second, there are data availability and homogeneity problems for all selected countries. 
Table 1 - Summary of selected panel and cross-sectional studies and different Natural Resources (NR) proxies.

\begin{tabular}{|c|c|c|c|c|}
\hline Reference & NR proxy & Panel & Cross-sectional & Main findings \\
\hline $\begin{array}{l}\text { Sachs and } \\
\text { Warner (1995) }\end{array}$ & $\begin{array}{l}\text { NR exports } \\
\text { over GDP }\end{array}$ & No & Yes & $\begin{array}{l}\text { Negative relationship between natural } \\
\text { resources and growth. }\end{array}$ \\
\hline $\begin{array}{l}\text { Manzono and } \\
\text { Rigobon (2006) }\end{array}$ & $\begin{array}{l}\text { NR exports } \\
\text { over GDP }\end{array}$ & Yes & No & $\begin{array}{l}\text { No effect or positive effect once fixed effects } \\
\text { are introduced into a model. }\end{array}$ \\
\hline $\begin{array}{l}\text { Arezki and Van } \\
\text { der Ploeg (2011) }\end{array}$ & $\begin{array}{l}\text { NR exports } \\
\text { over GDP }\end{array}$ & No & Yes & $\begin{array}{l}\text { Negative relationship between natural } \\
\text { resources and income per capita, especially in } \\
\text { countries with bad rule of law or bad policies. }\end{array}$ \\
\hline $\begin{array}{l}\text { Boschini et al. } \\
\text { (2013) }\end{array}$ & $\begin{array}{l}\text { NR exports } \\
\text { over GDP }\end{array}$ & Yes & Yes & $\begin{array}{l}\text { The interaction of ores and metals rents with } \\
\text { institutional quality has a negative effect on } \\
\text { growth. }\end{array}$ \\
\hline $\begin{array}{l}\text { Leite and } \\
\text { Weidmann } \\
\text { (1999) }\end{array}$ & $\begin{array}{l}\text { NR exports } \\
\text { over GNP }\end{array}$ & No & Yes & $\begin{array}{l}\text { Natural resources abundance creates } \\
\text { opportunities for rent-seeking behaviors and } \\
\text { it is an important factor in determining a } \\
\text { country's level of corruption. }\end{array}$ \\
\hline Davis (1995) & $\begin{array}{l}\text { NR exports } \\
\text { over total } \\
\text { exports }\end{array}$ & No & Yes & $\begin{array}{l}\text { Resource abundance have a positive } \\
\text { relationship with economic development. }\end{array}$ \\
\hline $\begin{array}{l}\text { Dietz et al. } \\
(2007)\end{array}$ & $\begin{array}{l}\text { NR exports } \\
\text { over total } \\
\text { exports }\end{array}$ & Yes & No & $\begin{array}{l}\text { Resource abundance has a negative effect on } \\
\text { genuine saving. }\end{array}$ \\
\hline Beck (2011) & $\begin{array}{l}\text { NR exports } \\
\text { over total } \\
\text { exports }\end{array}$ & No & Yes & $\begin{array}{l}\text { The paper tested for the existence of a } \\
\text { natural resources curse in financial system } \\
\text { development. The finance and growth } \\
\text { relationship seems as important for } \\
\text { resource-based economies as it is for other } \\
\text { economies, so that underinvestment in the } \\
\text { financial sector will have long-term negative } \\
\text { repercussions for economic growth. }\end{array}$ \\
\hline Daniele (2011) & $\begin{array}{l}\text { NR exports } \\
\text { over total } \\
\text { exports }\end{array}$ & Yes & No & $\begin{array}{l}\text { Human development is negatively correlated } \\
\text { with natural resources dependence, } \\
\text { but positively correlated with resource } \\
\text { abundance. These effects are particularly } \\
\text { significant in countries with comparatively } \\
\text { lower institutional quality. }\end{array}$ \\
\hline $\begin{array}{l}\text { Barajas et al. } \\
\text { (2013) }\end{array}$ & $\begin{array}{l}\text { NR exports } \\
\text { over total } \\
\text { exports }\end{array}$ & Yes & No & $\begin{array}{l}\text { The beneficial effect of financial deepening } \\
\text { on economic growth is smaller in oil } \\
\text { exporting countries. }\end{array}$ \\
\hline $\begin{array}{l}\text { Papyrakis and } \\
\text { Geragh (2003) }\end{array}$ & $\begin{array}{l}\text { NR production } \\
\text { over GDP }\end{array}$ & Yes & No & $\begin{array}{l}\text { Natural resources have a negative impact } \\
\text { on growth when considered in isolation, but } \\
\text { a positive impact on growth when include } \\
\text { in the analysis with other variables such as } \\
\text { corruption, investments, openness, terms } \\
\text { of trade, and schooling, and treating these } \\
\text { variables as independent. }\end{array}$ \\
\hline
\end{tabular}




\begin{tabular}{|c|c|c|c|c|}
\hline Reference & NR proxy & Panel & Cross-sectional & Main findings \\
\hline $\begin{array}{l}\text { Brunnschweiler } \\
(2008)\end{array}$ & $\begin{array}{l}\text { NR production } \\
\text { over GDP }\end{array}$ & No & Yes & $\begin{array}{l}\text { A positive relationship between natural } \\
\text { resources abundance and economic growth. }\end{array}$ \\
\hline $\begin{array}{l}\text { Collier and } \\
\text { Hoeffler (2009) }\end{array}$ & $\begin{array}{l}\text { NR rents over } \\
\text { GDP }\end{array}$ & Yes & No & $\begin{array}{l}\text { Natural resources abundance considerably } \\
\text { increases the potential of violent civil conflict. }\end{array}$ \\
\hline Ross (2001) & $\begin{array}{l}\text { NR rents over } \\
\text { GDP }\end{array}$ & Yes & No & $\begin{array}{l}\text { Oil exports are strongly associated with } \\
\text { authoritarian rule; that this effect is not limited } \\
\text { to the Middle East; and that other types of } \\
\text { mineral exports have a similar antidemocratic } \\
\text { effect, while other types of commodity } \\
\text { exports (agricultural commodities) do not. }\end{array}$ \\
\hline Auty (2001) & $\begin{array}{l}\text { NR rents over } \\
\text { GDP }\end{array}$ & Yes & No & $\begin{array}{l}\text { The presence of abundant natural resources } \\
\text { (especially minerals) leads to rent-seeking } \\
\text { behavior and corruption, thereby decreasing } \\
\text { the quality of governance, which in turn } \\
\text { negatively affects economic performance. }\end{array}$ \\
\hline $\begin{array}{l}\text { Bhattacharyya } \\
\text { and Collier } \\
(2013)\end{array}$ & $\begin{array}{l}\text { NR rents over } \\
\text { GDP }\end{array}$ & Yes & No & $\begin{array}{l}\text { Resource rents significantly reduce the } \\
\text { public capital stock. The adverse effect } \\
\text { on public capital is mitigated by good } \\
\text { institutions. The depletion of non-renewable } \\
\text { (mineral) resources reduces the public } \\
\text { capital stock whereas rents from sustainable } \\
\text { sources (forestry and agriculture) do not. }\end{array}$ \\
\hline $\begin{array}{l}\text { Bhattacharyya } \\
\text { and Hodler } \\
(2010)\end{array}$ & $\begin{array}{l}\text { NR rents per } \\
\text { capita }\end{array}$ & Yes & No & $\begin{array}{l}\text { The relationship between resource rents and } \\
\text { corruption depends on the quality of the } \\
\text { democratic institutions. }\end{array}$ \\
\hline
\end{tabular}

\section{Empirical models}

\subsection{Identification}

The objective of our empirical study is to evaluate the impact of non-renewable resources abundance on the development of agriculture and urbanization in a sample of African countries. We seek to verify two main hypotheses. The first (H1) suggests that oil and mineral rents can lead to the underdevelopment of the agriculture sector in resource-rich African countries (relation (1) Figure 1). The second (H2) indicates that oil and mineral rents are mostly invested in cities to develop infrastructure and services which, in turn, can attract more people and lead to an acceleration of urbanization (relation (4)). We suppose that the link between the two hypotheses is that poor performance of agriculture exposes the countries to two main prob-
Figure 1 - Oil and mineral rents and its relations with agriculture and urbanization.

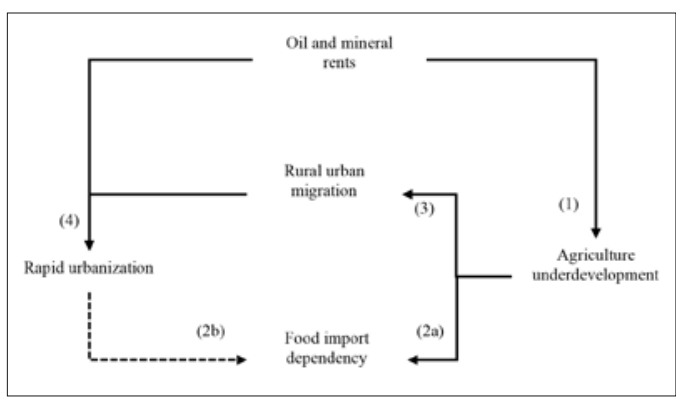

lems. First, an increase in rural-urban migration (3) since more than $2 / 3$ of Sub-Saharan African people work in the agricultural sector according to the World Bank estimations. The second problem is the food security. Indeed, faced with the inability of the agricultural sector to satisfy food needs locally, countries cover their deficits 
through imports (2a). Indirectly, food imports become more attractive for governments in order to feed growing urban populations rather than investing in agriculture ${ }^{3}(2 b)$.

Empirically, to test these hypotheses, we use a multiplicative interaction regression model. The advantage of a multiplicative interaction model compared to an additive interaction model resides in the fact that the coefficients in an additive model describe the effects of each independent variable on the dependent variable as constant (Ceteris Paribus), regardless of the level of the other independent variables; whereas the coefficients in an interactive model assume that the effects of each independent variable on the dependent variable are varying, depending on the level of the other independent variable. In our case, the interactive model enables us to adequately evaluate the impact of agricultural performance on rural-urban migration, food imports dependency and the urbanization rate in African countries conditional to their dependence level on natural resources revenues.

We test these hypotheses, using the following models with interaction effects:

$$
\begin{gathered}
\text { Agri }_{i t}=\beta_{0}^{1}+\beta_{1}^{1} \text { Rent }_{i t}+\sum_{j=3}^{p} \beta_{j}^{1} \text { Control }_{j, i t}+\varepsilon_{i t}^{1} \\
\text { Food_M_Dep }_{i t}=\beta_{0}^{2}+\beta_{1}^{2} \text { Agri }_{i t}+ \\
\beta_{2}^{2} \text { Agri }_{i t}^{*} \text { Rent }_{i t}+\sum_{j=3}^{p} \beta_{j}^{2} \text { Controls }_{j, i t}+\varepsilon_{i t}^{2} \\
\text { Food_M_Dep }_{i t}=\beta_{0}^{3}+\beta_{1}^{3} \text { Urban }_{i t}+ \\
\beta_{2}^{3} \text { Urban }_{i t} * \text { Rent }_{i t}+\sum_{j=3}^{p} \beta_{j}^{3} \text { Controls }_{j, i t}+\varepsilon_{i t}^{3}
\end{gathered}
$$

$$
\begin{aligned}
\text { Migration }_{i t}= & \beta_{0}^{4}+\beta_{1}^{4} \text { Agri }_{i t}+\beta_{2}^{4} \text { Agri }_{i t} * \text { Rent }_{i t}+ \\
& \sum_{j=3}^{p} \beta_{j}^{4} \text { Controls }_{j, i t}+\varepsilon_{i t}^{4}
\end{aligned}
$$

$$
\begin{aligned}
\text { Urban }_{i t}= & \beta_{0}^{5}+\beta_{1}^{5} \text { Rent }_{i t}+\beta_{2}^{5} \text { Agri }_{i t} * \text { Rent }_{i t}+ \\
& \sum_{j=3}^{p} \beta_{j}^{5} \text { Controls }_{j, i t}+\varepsilon_{i t}^{5}
\end{aligned}
$$

The dependent variables are: Agri $_{i t}$ agricultural value added per capita used as a measure of sectorial performance for country $i$ at time $t$; Food_M_Dept $t_{i t}$ food imports dependency measured by the share of food consumption covered by imports; Migration $_{i t}$ rural-urban migration. Ideally, a rural-urban migration estimate can be obtained from a direct survey that gives information on the type of previous residence. This is not the case for Africans countries for which no data are available. Therefore, we opted for an indirect estimation. We assume that the natural population growth (births-deaths) in both urban and rural areas has remained unchanged during the last fifteen years (estimation period) and we assume that the proportion of international migration remain stable. Under these assumptions, we can use simply the ratio of urban population to rural population as a proxy of rural-urban migration. A rise of this ratio would be a result of population movements from rural to urban areas; and $U_{r b a n}$ is the ratio of urban population out of the total population.

The explanatory variable of interest is Rent $t_{i t}$ which is the non-renewable resources abundance measured by the ratio of oil and mineral rents to GDP.

Controls $_{j, i t}$ is a set of other explanatory variables that affect the corresponding dependent variable. Theses variables include: yield $_{i t}$ which is grain yield as a proxy for agricultural productivity; land ${ }_{i t}$ is arable land in percent of total area; Rural $_{i t}$ is the percentage of rural population used as a proxy for labor availability. This approximation is justified because African agriculture is characterized by a high percentage of small family farms, where each member of the family has a role to play; demo ${ }_{i t}$ is population growth; Income $_{i t}$ is the gross domestic product (GDP) per capita measured in constant 2005 US dollars and Rural_income it $_{\text {it }}$ is the ratio of agricultural GDP measured in constant 2005 US dollars to rural population and used as a proxy for per capita income in rural area.

\footnotetext{
${ }^{3}$ World Bank and IMF structural adjustment programs supported this policy by eliminating government support for agriculture and poor farmers.
} 


\subsection{Expected results}

Equation (1) measures the direct impact of oil and mineral rents on agricultural performance. We test the null hypothesis that resource abundance has no significant effect on agricultural performance $\left(H_{0}: \beta_{1}=0\right)$ against the alternative hypothesis that resource abundance negatively affects agricultural performance $\left(H_{1}: \beta_{1}<0\right)$. The other explanatory variables are referred to productivity and inputs ${ }^{4}$ (land and labor). These variables are: yield $_{i t}$, land $_{i t}$ and Rural $_{i t}$. We expect positive coefficients for these three variables.

Equation (2a) evaluates the impact of agricultural performance on food import dependency conditional to oil and mineral rents. We expect $\beta_{1}<0$ and $\beta_{2}>0$ (Figure 2).

Figure 2 - Impact of agriculture performance on rural-urban migration and food import dependency depending on oil and mineral rents level.

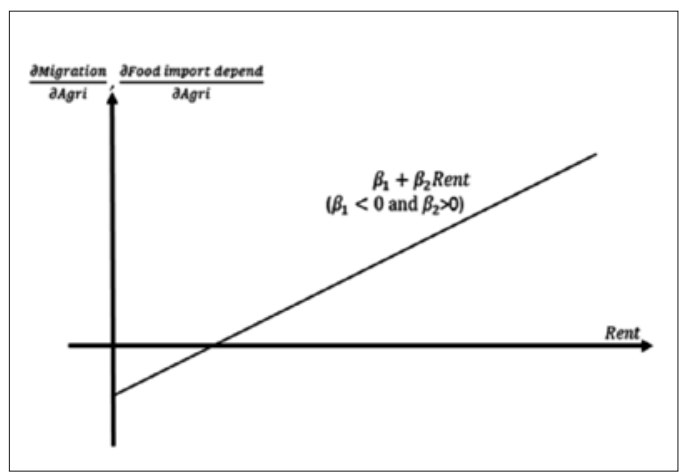

Equation (2b) evaluates the impact of urbanization dynamics on food imports dependency conditional to oil and mineral rents. Since we suppose that food imports become more attractive for decision makers in resource-rich countries in order to feed growing urban population rather than investing in agriculture, we expect a positive effect of urbanization on food imports dependency. Then, the coefficients $\beta_{1}$ and $\beta_{2}$ in equation (2b) should be positive (Figure 3 ).
Figure 3 - Impact of urbanization on food import dependency depending on oil and mineral rents level.

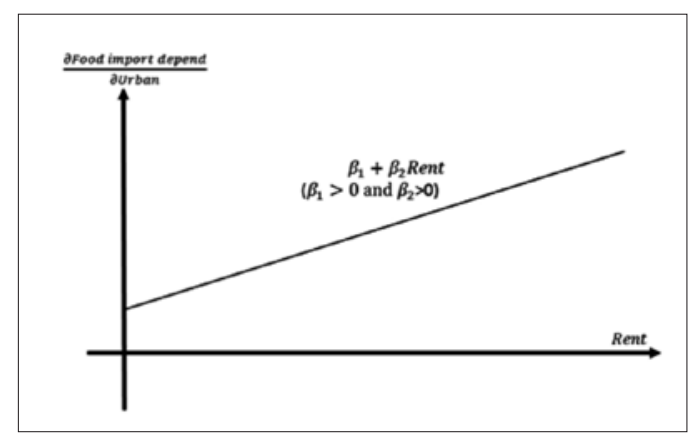

For both equations (2a) and (2b), we use two additional explanatory variables. First, population growth $\left(\right.$ demo $\left._{i t}\right)$. Intuitively, more population means more food needs. The sign and significance of the coefficient associated with this variable depend on the capacity of agricultural sector to satisfy additional needs. A significant positive coefficient would reflect that the additional food requirements are covered by imports. The second tested variable is Income $_{i t}$ which we expect to have a positive coefficient. In Africa, this phenomenon is very visible in cities where urban population - with a higher income level than in rural areas - is heavily dependent on imported wheat and rice (Tchamda et al., 2015).

Equation (3) measures the impact of agricultural performance on rural-urban migration conditional to oil and mineral rents. As illustrated in Figure 2, we expect that a marginal increase of agricultural performance to be associated with a decrease in rural-urban migration when a country is none or lowly dependent on oil and mineral rents $\left(\beta_{1}<0\right)$. The effect becomes positive when the dependence of oil and mineral rents exceeds a given threshold $\left(\beta_{2}<0\right)$. Therefore, the marginal increase in agricultural performance will be associated with an increase in migration. We use as control variables: population growth $\left(\right.$ demo $\left._{i t}\right)$ to capture the structural changes (its effect should be positive), and Rural_income ${ }_{i t}$ which hopefully will have a negative and significant effect.

\footnotetext{
${ }^{4}$ We explicitly ignore other inputs because Africa's agriculture uses minimal levels of fertilizers, pesticides and infrastructure facilities such as irrigation equipments, machinery, transport and communication.
} 
Finally, equation (4) tests both the direct effect of oil and mineral rents and the effect conditional to agricultural performance on urbanization dynamics. As shown in Figure 4, the coefficient $\beta_{1}$ captures the effect of an increase in oil and mineral rents on the urbanization rate when agricultural performance is absent.

Figure 4: Impact of oil and mineral rents on urbanization depending on agriculture performance.

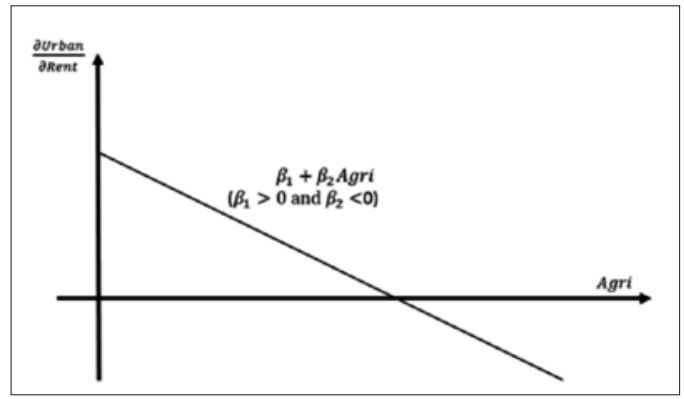

Since our hypothesis suggests that oil and mineral rents lead to an acceleration of urbanization, we expect to find a positive sign for $\beta_{1}$. For countries with good agricultural performance, we suppose that the urbanization rate grows at a slower rate because of low rural-urban migration. Then, the effect of resources rents on urbanization conditional to agricultural performance should be negative $\left(\beta_{2}<0\right)$.

\subsection{Estimation strategy}

We first estimate a static panel data model to control for the country-specific effects. Secondly, we estimate a dynamic panel data model to deal with missing variables effects.

\subsubsection{The Static Panel Data Estimations}

We start by estimating a static panel data model spelled as follows (equation 5).

$$
\begin{gathered}
y_{i t}=\beta^{\prime} X_{i t}+\alpha_{1}+c+v_{i t}, \\
i=1, \ldots, N(\text { country }) ; t=1, \ldots, T(\text { time })
\end{gathered}
$$

where $y_{i t}$ is the observed dependent variable for country $i$ at time $t, x_{i t}$ are regressors, $\beta$ the parameter vector to be estimated, $c$ the constant term and $v_{i t}$ the residual disturbance term with zero mean, constant variance, and supposed to be uncorrelated across time and individuals. The $\alpha_{i}$ terms represent the country-specific effects and capture the unobserved heterogeneity in the model.

We first test for the presence of panel heterogeneity using the redundant fixed effect test. The null hypothesis of the redundant fixed effect is that the pooled regression model is more appropriate $\left(H_{0}: \alpha_{1}=\ldots=\alpha_{N}=\alpha\right)$, with the alternative hypothesis being that the fixed effect model is preferable. Then, we test both fixed and random effects models. The fixed effects model involves estimating a parameter $\left(\alpha_{i}\right)$ for each country, in our case the 39 selected countries. The random effects model assumes that country-specific terms $\left(\alpha_{i}\right)$ are randomly distributed. In this case, we do not need to estimate a parameter for each country and this can be considerable as an efficiency gain. However, the random effects estimator will be inconsistent due to the presence of correlation between the country-specific effects and one or more independent variables (Baltagi, 1995). We test for random effects estimator consistency in our analysis below by conducting a standard Hausman test. A significant value for the Hausman test statistic would mean that the random effects estimators are inconsistent and that fixed effects estimates are more appropriate. We can easily estimate these models by using standard methods (Least Squares Dummy Variables or LSDV) for fixed effects model and Generalized Least Squares (GLS) for random effects model or Ordinary Least Squares (OLS) for both, if we can assume heteroskedastic disturbances.

\subsubsection{The Dynamic Panel Data Estimations}

In addition to the static approach, we also test for dynamic effects in the models. A dynamic approach may be particularly relevant to evaluate the influence of natural resources rents on agricultural development and urbanization trends. Dynamic panel data models use the lags of the dependent variable as explanatory variables (see equation 6).

$$
\begin{gathered}
y_{i t}=\gamma y_{i t-1}+\beta^{\prime} X_{i t}+\alpha_{1}+c+v_{i t}, \\
i=1, \ldots, N ; t=1, \ldots, T
\end{gathered}
$$


It is evident that the model suffers from an endogeneity problem, because $y_{t i-1}$ is correlated with $\alpha_{i}$. In this case, the standard estimators (GLS and OLS) would be inappropriate. To solve this problem, we use the Generalized Method of Moments (GMM) approach proposed by Arellano and Bond (1991). We start by transforming the equation into first differences to eliminate the bias arising from individual heterogeneity (equation 7) and then we estimate the transformed equation through the GMM method using lagged values of the endogenous variables as instruments.

$$
\begin{gathered}
\Delta y_{i t}=\gamma \Delta y_{i t-1}+\beta^{\prime} \Delta X_{i t}+\Delta v_{i t,} \\
i=1, \ldots, N ; t=1, \ldots, T
\end{gathered}
$$

The consistency of the GMM estimator depends on the validity of the assumption that the error terms do not exhibit serial correlation and on the validity of the instruments. To address these issues, we use two specification tests suggested by Arellano and Bond (1991) and Sargan (1958). The first one, commonly called "m-test" examines the presence of serial correlation in error terms. As, we run the test on the differenced equation, we only report the test for second-order serial correlation. The second one, commonly called "J-test" of over-identifying restrictions, regresses the residuals from a GMM regression on all instruments and test if all instruments are uncorrelated with the error term. For both tests, we should not reject the null hypothesis to confirm the consistency of the GMM estimators. We note that Arellano and Bond (1991) compared, using simulations, the performance of GMM, OLS, and Within-Group (WG) estimators and they found that GMM estimators exhibit the smallest bias and variance.

\section{Data and statistical analysis}

\subsection{Data description and sources}

The data are gathered from the World Bank (World Development Indicators), the Food and Agriculture Organization of the United Nations (FAO) and the World Urbanization Prospects and Millennium Development Goals (United Nations). All these sources are characterized by considerable lack of data, forcing us to make an arbitrage concerning the number of countries in the sample, the number of variables to include in the equations and the estimation period. In fact, according to the United Nations, the total number of African countries is 54. Out of this group, 15 countries were excluded due to missing data, both on the dependent and the control variables. We assume that the resulting panel of countries is not endogenous. The estimation is based on annual data span from 2000 to 2013. The selected variables are summarized in Table 2 and the list of selected countries is presented in Table 3.

\begin{tabular}{|c|c|c|c|}
\hline Variable & Abbreviation & Description & Source \\
\hline $\begin{array}{l}\text { Oil and } \\
\text { mineral rents } \\
\text { dependency } \\
\text { indicator }\end{array}$ & Rent & $\begin{array}{l}\text { We include the sum of oil rents, natural gas rents, } \\
\text { coal rents (hard and soft) and mineral rents. } \\
\text { According to the World Bank, the estimates of } \\
\text { a resource rents are calculated as the difference } \\
\text { between the price of a commodity and its } \\
\text { average cost of production. This is done by } \\
\text { estimating the world price of units of specific } \\
\text { commodities and subtracting estimates of } \\
\text { average unit costs of extraction or harvesting } \\
\text { costs (including a normal return on capital). } \\
\text { These unit rents are then multiplied by the } \\
\text { physical quantities countries extract or harvest } \\
\text { to determine the rents for each commodity as a } \\
\text { share of gross domestic product (GDP). }\end{array}$ & $\begin{array}{l}\text { Estimates based } \\
\text { on sources and } \\
\text { methods described } \\
\text { in The Changing } \\
\text { Wealth of Nations: } \\
\text { Measuring Sustainable } \\
\text { Development in the } \\
\text { New Millennium (World } \\
\text { Bank, 2011). }\end{array}$ \\
\hline
\end{tabular}

Table 2 - Data description and sources. 


\begin{tabular}{|c|c|c|c|}
\hline Variable & Abbreviation & Description & Source \\
\hline $\begin{array}{l}\text { Agriculture } \\
\text { performance }\end{array}$ & Agri & $\begin{array}{l}\text { Agriculture value added (VA) divided by } \\
\text { total population. Agriculture VA is the net } \\
\text { output of agriculture sector after adding up all } \\
\text { outputs and subtracting intermediate inputs. } \\
\text { It is calculated without making deductions for } \\
\text { depreciation of fabricated assets or depletion } \\
\text { and degradation of natural resources. }\end{array}$ & $\begin{array}{l}\text { World Bank national } \\
\text { accounts data, and } \\
\text { OECD National } \\
\text { Accounts data files. }\end{array}$ \\
\hline Cereal yield & yield & $\begin{array}{l}\text { Cereal yield, measured as kilograms per } \\
\text { hectare of harvested land, includes wheat, rice, } \\
\text { maize, barley, sorghum and others grains. }\end{array}$ & FAO \\
\hline Arable land & land & $\begin{array}{l}\text { Arable land as defined by the FAO measured as } \\
a \% \text { of total land area. }\end{array}$ & FAO \\
\hline $\begin{array}{l}\text { Rural } \\
\text { population }\end{array}$ & Rural & $\begin{array}{l}\text { Rural population refers to people living in rural } \\
\text { areas as defined by national statistical offices. It } \\
\text { is calculated as \% of total population. }\end{array}$ & $\begin{array}{l}\text { World Bank estimates } \\
\text { based on United Nations, } \\
\text { World Urbanization } \\
\text { Prospects. }\end{array}$ \\
\hline $\begin{array}{l}\text { Food import } \\
\text { dependency }\end{array}$ & Food_M_Dep & $\begin{array}{l}\text { Share of food imports in total food } \\
\text { consumption. Total food consumption is } \\
\text { derived from a Demand/Supply equilibrium } \\
\text { equation. }\end{array}$ & $\begin{array}{l}\text { World Bank estimates } \\
\text { from the Comtrade } \\
\text { database, United Nations } \\
\text { Statistics Division. }\end{array}$ \\
\hline $\begin{array}{l}\text { Population } \\
\text { growth }\end{array}$ & demo & Annual population growth rate. & $\begin{array}{l}\text { World Bank from United } \\
\text { Nations Population } \\
\text { Division, World } \\
\text { Population Prospects. }\end{array}$ \\
\hline $\begin{array}{l}\text { Prosperity } \\
\text { indicator }\end{array}$ & Income & $\begin{array}{l}\text { GDP converted to } 2005 \text { constant international } \\
\text { dollars using Purchasing power parity (PPP) } \\
\text { rates divided by total population. }\end{array}$ & World Bank, WDI \\
\hline $\begin{array}{l}\text { Rural area } \\
\text { standard of } \\
\text { living indicator }\end{array}$ & Rural_income & $\begin{array}{l}\text { Agriculture value Added expressed in constant } \\
2005 \text { US\$ and divided by rural population. }\end{array}$ & World Bank, WDI \\
\hline $\begin{array}{l}\text { Urban } \\
\text { population }\end{array}$ & Urban & $\begin{array}{l}\text { Share of people living in urban areas as defined } \\
\text { by national statistical offices on total population. }\end{array}$ & $\begin{array}{l}\text { United Nations, World } \\
\text { Urbanization Prospects. }\end{array}$ \\
\hline
\end{tabular}

Table 3 - List of the selected countries.

\begin{tabular}{|c|c|c|c|c|c|c|c|c|}
\hline$n^{\circ}$ & Country & $\begin{array}{c}\text { Rent to } \\
G D P\end{array}$ & $n^{\circ}$ & Country & $\begin{array}{c}\text { Rent to } \\
G D P\end{array}$ & $n^{\circ}$ & Country & $\begin{array}{c}\text { Rent to } \\
G D P\end{array}$ \\
\hline 1 & Libya & 54,78 & 14 & Tunisia & 5,87 & 27 & Senegal & 0,88 \\
\hline 2 & Angola & 52,31 & 15 & Ghana & 5,60 & 28 & Burundi & 0,54 \\
\hline 3 & Gabon & 43,73 & 16 & South Africa & 4,58 & 29 & Liberia & 0,49 \\
\hline 4 & Algeria & 37,59 & 17 & Zimbabwe & 4,58 & 30 & Ethiopia & 0,40 \\
\hline 5 & Mauritania & 31,14 & 18 & Mozambique & 4,50 & 31 & Swaziland & 0,37 \\
\hline 6 & Nigeria & 30,91 & 19 & Eritrea & 4,17 & 32 & Sierra Leone & 0,34 \\
\hline 7 & Equatorial Guinea & 29,25 & 20 & Burkina Faso & 3,74 & 33 & Madagascar & 0,28 \\
\hline 8 & Chad & 25,65 & 21 & Botswana & 3,45 & 34 & Uganda & 0,13 \\
\hline 9 & Sudan & 15,87 & 22 & Tanzania & 2,43 & 35 & Rwanda & 0,09 \\
\hline 10 & Zambia & 11,14 & 23 & Morocco & 2,05 & 36 & Kenya & 0,07 \\
\hline 11 & Guinea & 9,78 & 24 & Niger & 2,03 & 37 & Central African Rep. & 0,06 \\
\hline 12 & Cameroon & 8,27 & 25 & Namibia & 1,57 & 38 & Benin & 0,06 \\
\hline & Mali & 6,63 & 26 & Togo & 1,46 & 39 & Malawi & 0,03 \\
\hline
\end{tabular}


Table 4 presents descriptive statistics (i.e. top 10 group with an average rate close to $33 \%$, mean value, maximum and minimum values, compared to the sample average $(10.4 \%)$. In adstandard deviation and number of observations) for the selected variables. For each variable, we compare computed averages for the whole sample with the average of the top 10 resource-rich Africans countries. It is evident from the data, that natural resources dependency is high for the dition, the top 10 group has a lower agricultural performance in terms of value added per capita, yield and availability of land and labor compared to the whole sample. The Urbanization rate is also higher in the top 10 group (48.6\%) compared to the sample average $(37.6 \%)$.

Table 4 - Descriptive statistics of selected variables (2000-2013).

\begin{tabular}{|l|c|c|c|c|c|c|c|}
\hline \multirow{2}{*}{ Variable } & \multirow{2}{*}{ Unit } & \multicolumn{2}{c|}{ Mean } & \multirow{2}{*}{ Max } & \multirow{2}{*}{ Min } & \multirow{2}{*}{ Std. Dev. } & \multirow{2}{*}{ Obs. } \\
\cline { 3 - 4 } & & All & Top $10^{a}$ & & & \\
\hline Rent & $\%$ & 10,4 & 33,2 & 84,7 & 0,0 & 17,2 & 546 \\
\hline Agri & 000 \$/cap. & 35,2 & 32,9 & 163,2 & 1,5 & 30,8 & 478 \\
\hline yield & Kg/hect. & 1252,4 & 1107,3 & 4412,6 & 130,7 & 627,9 & 532 \\
\hline land & $\%$ & 13,5 & 6,7 & 48,7 & 0,3 & 12,4 & 542 \\
\hline Rural & $\%$ & 62,4 & 51,4 & 91,8 & 13,3 & 17,4 & 546 \\
\hline Food_M_Dep & $\%$ & 28,0 & 25,7 & 101,1 & 0,0 & 22,4 & 355 \\
\hline demo & $\%$ & 0,5 & 0,3 & 6,6 & $-3,0$ & 1,1 & 546 \\
\hline Income & US\$/cap. & 1778,9 & 3661,8 & 16847,6 & 132,6 & 2700,3 & 546 \\
\hline Rural income & US\$/cap. & 324,5 & 529,4 & 2889,8 & 20,3 & 418,2 & 498 \\
\hline Urban & $\%$ & 37,6 & 48,6 & 86,7 & 8,2 & 17,4 & 546 \\
\hline
\end{tabular}

Note: (a) Top 10 highly resource dependent countries (see Table 2).

\subsection{Correlation between oil and minerals rents and agriculture}

Figure 5 shows that on average over the period from 2000 to 2013, agricultural value added per capita is negatively correlated with oil and minerals rents (in percentage of GDP). These two variables have a correlation coefficient of -0.10 . In other words, when a country strongly depends on revenues from extractive industries, there is a probability that its agricultural production will be lower and vice versa. However, this chart does not mean that there is a causal link between resources rents and agricultural performance.

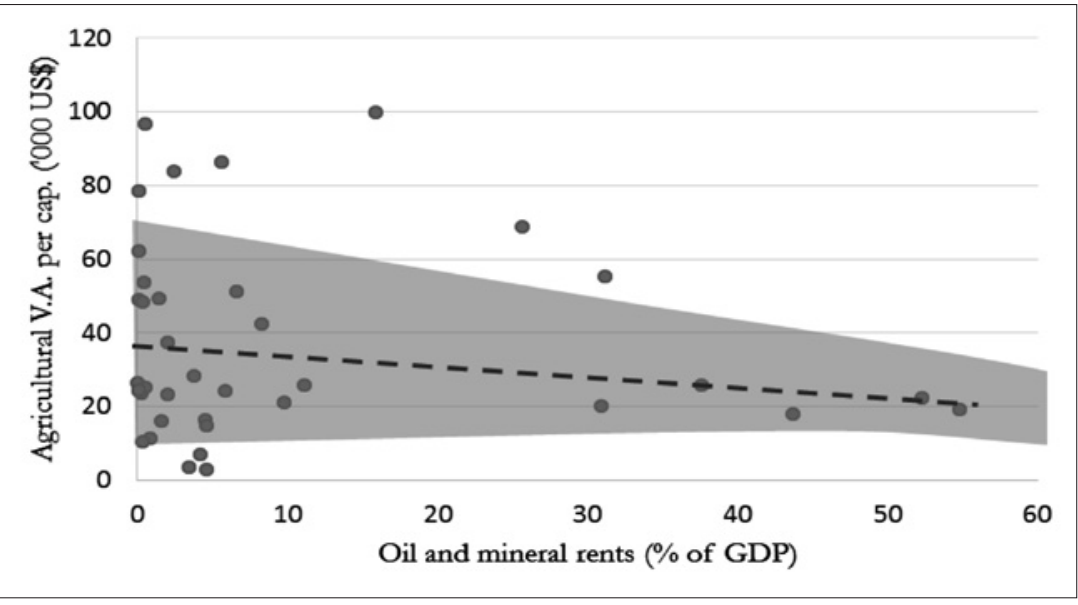

Figure 5 - Natural resources rents and agricultural performance. 


\subsection{Correlation between oil and mineral rents and urbanization}

Similarly, Figure 6 shows that on average over the period 2000-2013, the urbanization rate in Africa is positively correlated with oil and minerals rents. These two variables have a correlation coefficient of 0.54 . This result suggests that countries highly dependent on natural resources revenues tend to have a higher proportion of urban population. However, this chart does not confirm a causal link between natural resources dependency and urbanization levels.

In addition, the positive correlation between urbanization and natural resources rents does not mean that urban people live in better conditions. Indeed, if we classify the African countries according to the share of resources rents in GDP (Table 5), we can see that the group of countries heavily dependent show higher percentages of urban population living in unhealthy housing (with less access to water and sanitation) compared to the group of countries less dependent.

Figure 6 - Natural resources rents and urbanization.

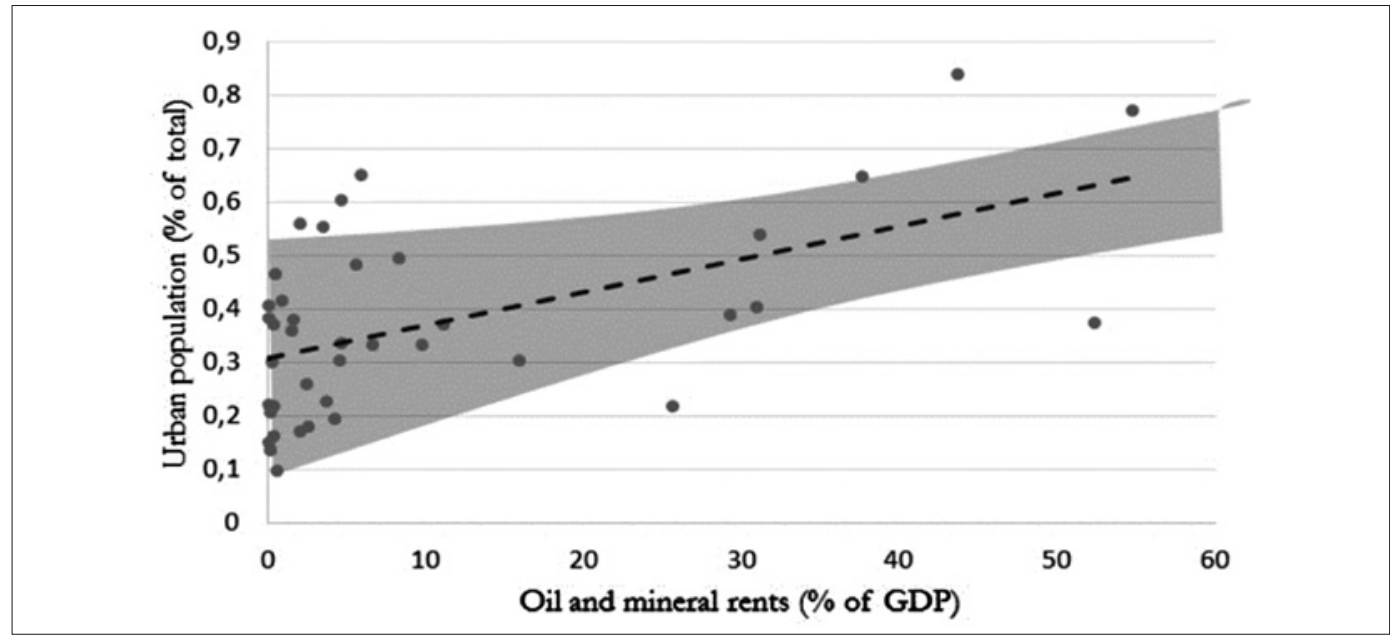

Table 5 - Natural resources rents and urbanization conditions.

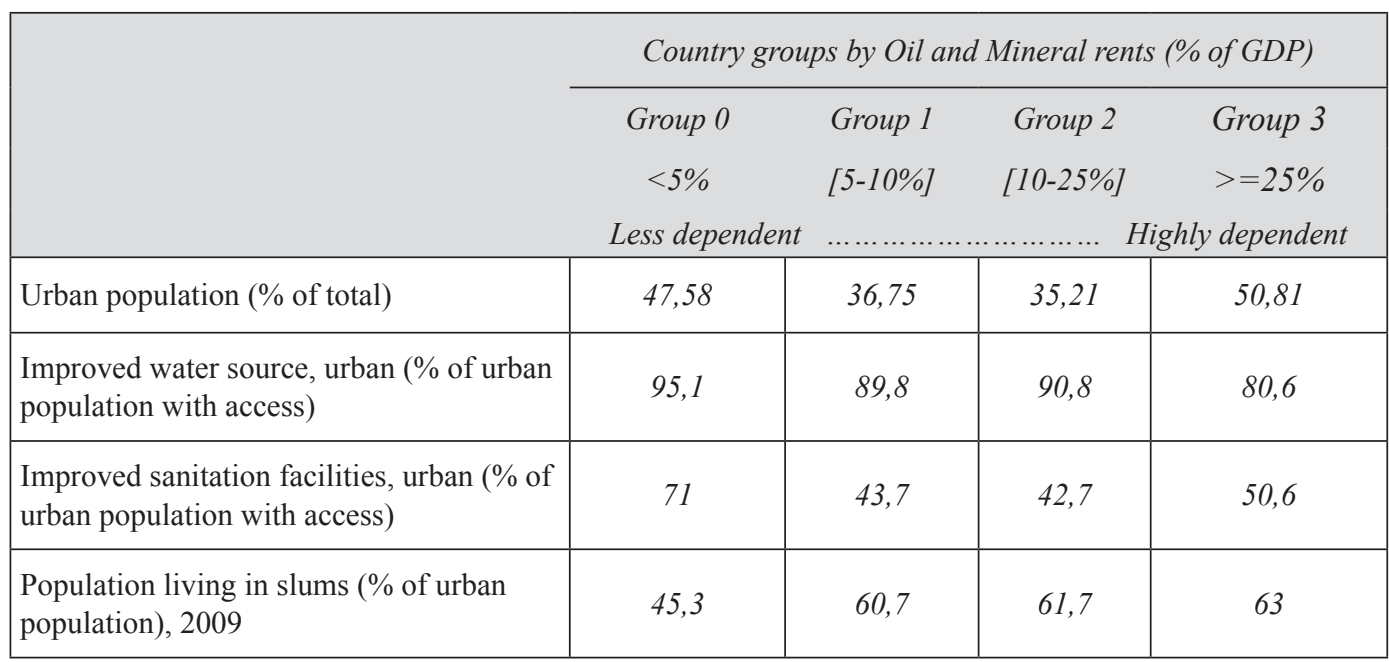

Source: World Bank and United Nation Millennium Development Goals database. 


\section{Results}

\subsection{Econometric validation of static and dynamic panel data estimations}

Table 6 presents the results of the static panel regressions and Table 7 reports the results of the dynamic panel regressions. Each column, in Tables 6 and 7, presents the best specification for the corresponding equation.

In order to validate the model, we run some important specification tests. For static panel regressions, we first conduct the redundant fixed effect test (R-test) for each regression. The result shows that the R-test statistic is significant for all regressions, suggesting a presence of a country specific effect. Moreover, we run the Hausman test to check if this specific effect is fixed or random. The result suggests a fixed effect specification for all regressions as the test is strongly significant (Prob(H-test) $<5 \%$ ). For dynamic panel regressions, we conduct two specification tests (m-test and J-test) to validate our results. As we can see, for all estimated regressions, the m-test is insignificant suggesting the absence of second order serial correlation in residuals, whereas, the J-test of over-identifying restrictions provides support for our choice of instruments.

\subsection{Analysis of the Static Panel Data Estimations}

Column 1 in Table 6 presents the estimated coefficients for equation (1) using panel fixed effects. The results show that oil and minerals rents have a negative and significant effect on agricultural performance. These findings are in line with the first hypothesis (H1), which suggests that oil and minerals rents can lead to the underdevelopment of the agricultural sector in resource-rich African countries. Looking at the control variables, as expected, the two main production factors: arable land (Land) and work force (Rural) as well as cereal yields (Yield) are significant and positive determinants of agricultural performance in African countries. Columns (2) and (3) report the estimated coefficients for equation (2a) and (2b) respectively. The result shows a negative and signif- icant effect of agricultural performance (Agri) on food import dependency at $1 \%$ level when the conditioning variable (Rent) is absent. The coefficient is equal to -0.27 . Therefore, a one-percentage point increase in agricultural performance leads to a decrease in food imports dependency of 0.27 percentage points, on average, in the selected panel of African countries. The coefficient of the interaction term between agricultural performance and resource rents (equal to 0.08 ) is positive and significant at the $10 \%$ level. This result can be interpreted as follow: the marginal increase in agricultural performance leads to an increase - i.e. becomes more positive - in food import dependency when a country in highly resource rent dependent (Djella et al., 2019). Urbanization is a significant and positive determinant of food import dependency. The estimated coefficient is equal to 0.655 with interaction of agriculture performance and resource rents as showed in the equation 2a (column 2), and 0.667 with the interaction of urbanization and resource rents in the equation $2 \mathrm{~b}$ (column 3 ). The conditional impact of urbanisation to resource rents is positive and significant at the $1 \%$ level $(0.137)$ suggesting that urbanization leads to more food import dependency in countries with high resource rents. The estimation results for equation (3) are shown in column (4). Agricultural performance has a negative and significant effect on rural-urban migration, but in terms of magnitude the effect is only 0.05 . This would suggest that a one-percentage point increase in agricultural performance leads to a decrease in migration flows by only $0.05 \%$. The interaction between agricultural performance and resources rents is positively significant at the $1 \%$ level. This means that agricultural performance plays the opposite role in countries highly dependent on resources rents. Perhaps this is because the agriculture sector, in resource rich-countries, cannot offer more job opportunities and better living standards than in the oil and minerals sector. The control variables used in equation (3) show evidence that population growth affects positively rural-urban migration and is statistically significant at level of $1 \%$; and rural revenue effect is, as expected, negative but not 
Table 6 - Static Panel Estimations.

\begin{tabular}{|c|c|c|c|c|c|}
\hline \multirow{3}{*}{$\begin{array}{l}\text { Dependent } \\
\text { variable }\end{array}$} & \multirow{3}{*}{$\begin{array}{c}\text { Production } \\
\text { Agri } \\
\text { (1) } \\
\end{array}$} & \multirow{2}{*}{\multicolumn{2}{|c|}{$\begin{array}{c}\text { Food dependency } \\
\text { Food_M_Dep }\end{array}$}} & \multirow{3}{*}{$\begin{array}{c}\text { Migration } \\
\text { Migration } \\
\text { (4) }\end{array}$} & \multirow{3}{*}{$\begin{array}{c}\text { Urbanization } \\
\text { Urban } \\
\text { (5) }\end{array}$} \\
\hline & & & & & \\
\hline & & (2) & (3) & & \\
\hline Agri & & $\begin{array}{l}-0,272^{* * *} \\
(0,031)\end{array}$ & $\begin{array}{l}-0,266^{\text {*** }} \\
(0,035)\end{array}$ & $\begin{array}{l}-0,047 \\
(0,019)\end{array}$ & $\begin{array}{r}0,172 \\
(0,032)\end{array}$ \\
\hline Agri $\times$ Rent & & $\begin{array}{r}0,080^{*} \\
(0,046)\end{array}$ & & $\begin{array}{l}0,223^{* * *} \\
(0,029)\end{array}$ & $\begin{array}{l}-0,217 \\
(0,044)\end{array}$ \\
\hline Urban & & $\begin{array}{l}0,655^{* * *} \\
(0,031)\end{array}$ & $\begin{array}{r}0,667^{* * *} \\
(0,031)\end{array}$ & & \\
\hline Urban $\times$ Rent & & & $\begin{array}{r}0,137^{* * *} \\
(0,025)\end{array}$ & & \\
\hline Rent & $\begin{array}{l}-0,354^{* * *} \\
(0,091)\end{array}$ & & & & $\begin{array}{r}0,160 \\
(0,036)\end{array}$ \\
\hline Constant & $\begin{array}{l}-0,103^{* * *} \\
(0,037)\end{array}$ & $\begin{array}{r}0,086^{* *} \\
(0,035) \\
\end{array}$ & $\begin{array}{r}0,0644^{*} \\
(0,033)\end{array}$ & $\begin{array}{r}0,042 \\
(0,030) \\
\end{array}$ & $\begin{array}{r}0,123 \\
(0,029) \\
\end{array}$ \\
\hline Land & $\begin{array}{r}0,545^{* * *} \\
(0,078)\end{array}$ & & & & \\
\hline Rural & $\begin{array}{r}0,479^{* * *} \\
(0,143)^{*}\end{array}$ & & & & \\
\hline Yield & $\begin{array}{r}0,104^{* *} \\
(0,047)\end{array}$ & & & & \\
\hline Rural_income & & & & $\begin{array}{r}-0,050 \\
(0,040) \\
\end{array}$ & \\
\hline Income & & & & & $\begin{array}{r}1,076 \\
(0,048)\end{array}$ \\
\hline Demo & & & & $\begin{array}{r}0,561^{* * *} \\
(0,055)\end{array}$ & \\
\hline Adj, R2 & 0,582 & 0,415 & 0,421 & 0,394 & 0,612 \\
\hline F-Statistic & 17,009 & 76,209 & 78,036 & 78,466 & 188,862 \\
\hline Prob(F-Stat) & 0,000 & 0,000 & 0,000 & 0,000 & 0,000 \\
\hline Redundant fixe & ect test ( $H_{0}: P$ & regression & del is more & riate) & \\
\hline R-Statistic & 18,182 & 34,380 & 34,206 & 269,781 & 442,398 \\
\hline Prob(R) & 0,000 & 0,000 & 0,000 & 0,000 & 0,000 \\
\hline Hausman test & Random effect & is more appr & riate) & & \\
\hline H-Statistic & 9,090 & 18,817 & 18,091 & 17,672 & 20,587 \\
\hline $\operatorname{Prob}(\mathrm{H})$ & 0,059 & 0,000 & 0,000 & 0,001 & 0,000 \\
\hline Obs. & 461 & 319 & 319 & 478 & 478 \\
\hline $\mathrm{N}$ & 37 & 30 & 30 & 38 & 38 \\
\hline
\end{tabular}

significant. The estimated coefficients for equa- indicates that oil and minerals rents are mosttion 4 are presented in column (5). Our find- ly invested in cities in order to develop infraings support the second hypothesis $(\mathrm{H} 2)$, which structures and services. This can attract more 
people and lead to an acceleration of urbanization as the coefficient associated with resource rents is positive and significant at level of $1 \%$ (0.16). When we test agricultural performance as a conditioning variable, the effect becomes negative (-0.217). This can imply that the effect on the urbanization rate is positive in countries highly dependent on resources rents but with poor agriculture performance.

\subsection{Analysis of the Dynamic Panel Data Estimations}

Table 7 reports the estimation results of a dynamic panel using the GMM method with instruments taken from lags dated from $\mathrm{t}-2$ to $\mathrm{t}-5$. We observe a positive and statistically significant effect of the lagged dependent variable for all regressions. This means that the omitted variable

Table 7 - Dynamic Panel Estimations.

\begin{tabular}{|c|c|c|c|c|c|}
\hline \multirow{3}{*}{$\begin{array}{l}\text { Dependent } \\
\text { variable }\end{array}$} & Production & \multicolumn{2}{|c|}{ Food dependency } & Migration & \multirow{2}{*}{$\frac{\text { Urbanization }}{\text { Urban }}$} \\
\hline & Agri & Food_ & $\overline{D e p}$ & Migration & \\
\hline & (1) & (2) & (3) & (4) & (5) \\
\hline lag & $\begin{array}{r}0,687^{* * *} \\
(0,0889)\end{array}$ & $\begin{array}{r}0,137^{* * *} \\
(0,0150)^{* *}\end{array}$ & $\begin{array}{r}0,170 \\
(0,0069)\end{array}$ & $\begin{array}{r}0,959^{* * *} \\
(0,0001)^{* *}\end{array}$ & $\begin{array}{r}1,009^{* * * *} \\
(0,0035)^{*}\end{array}$ \\
\hline Agri & & $\begin{array}{r}-0,248^{* * * *} \\
(0,0565)\end{array}$ & $\begin{array}{r}-0,113 \\
(0,0396)\end{array}$ & $\begin{array}{r}-0,017^{* * *} \\
(0,0001)^{*}\end{array}$ & $\begin{array}{r}0,009^{* * *} \\
(0,0009)^{* *}\end{array}$ \\
\hline Agri $\times$ Rent & & $\begin{array}{r}0,195^{* * *} \\
(0,0431)\end{array}$ & & $\begin{array}{r}0,004^{* * *} \\
(0,0001)\end{array}$ & $\begin{array}{r}0,014 \\
(0,0012)\end{array}$ \\
\hline Urban & & $\begin{array}{r}1,911^{* * *} \\
(0,1734)^{* *}\end{array}$ & $\begin{array}{r}-0,475^{* * *} \\
(0,0740)\end{array}$ & & \\
\hline Urban $\times$ Rent & & & $\begin{array}{r}0,1333^{* * *} \\
(0,0373)\end{array}$ & & \\
\hline Rent & $\begin{array}{r}-0,607^{* * *} \\
(0,1720)\end{array}$ & & & & $\begin{array}{r}0,012 \\
(0,0012)\end{array}$ \\
\hline Land & $\begin{array}{r}1,617^{* *} \\
(0,7354)\end{array}$ & & & & \\
\hline Rural & $\begin{array}{r}6,377 \\
(0,9439)\end{array}$ & & & & \\
\hline Yield & $\begin{array}{r}0,406 \\
(0,0855)\end{array}$ & & & & \\
\hline Rural_income & & & & $\begin{array}{r}-0,009 \\
(0,0004)\end{array}$ & \\
\hline Income & & & & & \\
\hline Demo & & & & & $\begin{array}{r}0,012^{* * *} \\
(0,0017) \\
\end{array}$ \\
\hline Adj, R2 & 0,454 & 0,433 & 0,449 & 0,835 & 0,808 \\
\hline J-Statistic & 23,790 & 21,455 & 24,123 & 30,263 & 28,423 \\
\hline $\operatorname{Prob}(j)$ & 0,162 & 0,612 & 0,512 & 0,651 & 0,442 \\
\hline m-Statistic & 1,205 & $-0,564$ & $-0,404$ & 0,877 & 0,984 \\
\hline $\operatorname{Prob}(m)$ & 0,228 & 0,573 & 0,686 & 0,381 & 0,325 \\
\hline Obs. & 376 & 285 & 285 & 405 & 405 \\
\hline $\mathrm{N}$ & 35 & 29 & 29 & 37 & 37 \\
\hline
\end{tabular}

Notes: $* * *, * *$, and $*$ indicate significance level at $1 \%, 5 \%$, and $10 \%$, respectively, against a two sided alternative, figures in parentheses are cluster standard errors and they are robust to arbitrary heteroskedasticity and arbitrary intra-group correlation. 
bias is now reduced. Similar to result obtained from the static panel specification, we find a significant negative impact of resource rents on agricultural performance (column 1). We also find a positive impact of agricultural performance on food imports dependency that is statistically significant at the $1 \%$ level (columns 2 and 3 ). The impact of resources rents on food imports dependency is positive whether it interacts with agricultural performance (column 2) or with urbanization (column 3). As obtained in the static estimation, agricultural performance is a determinant for rural-urban migration. The impact becomes positive and significant with interaction of resources rents (column 4$)^{5}$ but the estimated coefficient values is much smaller than the one obtained in a static specification. This may be due to the introduction of a lagged dependent variable. Our estimation indicates a positive and significant effect of resource rents on urbanization at level of $1 \%$ (column 5 ). ${ }^{6}$ We do not find the expected sign for the interaction between agriculture and resources rents. The coefficient is positive but too small, as it only equals 0.014 .

\section{Conclusion}

This paper examines the mechanism through which natural resources lead to poor agricultural performance and rapid urbanization in African countries. Using static and dynamic panel models covering the period 2000-2013 and 39 African countries, we show that resources rents affect negatively agricultural value added and positively food imports dependency. This because the resource-rich countries neglect the non-extractive industry, in particular, the agriculture sector. Consequently, this policy orientation tends to expose food security in these countries to international price food fluctuations. Djella et al. (2019) which show a significant impact of oil export on the food dependency in terms of food import and the food insecurity (undernourishment) founded the same result.
Our results show a positively significant impact of resources rents on rural-urban migration and therefore the urbanization rate. These findings imply that resource-rich countries indeed have a tendency to neglect agriculture that can be justified by attractive world food commodity prices. However, since 2007-2008, food prices have shown a higher volatility and this situation can present a food security risk for millions of Africans (Kalkuhl et al., 2016).

The positive impact of natural resources rents on the urbanization rate can be interpreted as both a cause and a consequence of policy choices. On the one hand, as policy-makers in resource-rich nations tend to invest in extractive industries to the detriment of other sectors like agriculture, they create a push factor for rural migration. On the other hand, as these policy-makers allocate the rents in priority to develop infrastructures in urban area (generally in port cities), they create some pull factors to rural population looking for a better life. In fact, this could explain the massive rural-urban migration which contributes to the ongoing debate about the inequality of resource rents distribution in a society.

Generally, urbanization and economic growth are closely linked. The strong positive correlation between these two indicators has been numerously documented. ${ }^{7}$ There is no doubt that much of the causation goes from economic growth to increased urbanization. However, as countries grow, they undergo structural changes. Labor forces are reallocated from rural agriculture to urban manufacturing and services sectors (Michaels et al., 2012) and when urbanization occurs without industrialization, serious urban and development problems can arise (Gollin et al., 2013). This is particularly the case for most African countries. The statistical analysis presented in Table 5 shows evidence that the urbanization in rich-resource African countries is associated with huge social problems (expansion of urban slums, limited access to improved water and sanitations facilities).

\footnotetext{
5 The variable Demo was tested but the results showed an insignificant effect.

6 The variable Income was excluded from equation 4 (column 5) after showed non-significant effect.

7 See for instance World Bank (2009) and Henderson (2002; 2010).
} 
Further research is needed to focus on this complex causal link between urbanization problems and resource dependence in rich-resources African countries. Future studies should also evaluate the final impact of rapid urbanization in many resource-rich African countries. A time-series analysis of this group of countries, over a longer period, will also allow for more conclusive results.

\section{References}

Arellano M., Bond S., 1991. Some tests of specification for panel data: Monte Carlo evidence and an application to employment equations. The Review of Economic Studies, 58(2): 277-297.

Arezki R., Gylfason T., 2013. Resource rents, democracy, corruption and conflict: Evidence from sub-Saharan Africa. Journal of African Economies, 22(4): 552-569.

Auty R.M., 1986. Resource-based industrialization and country size: Venezuela and Trinidad and Tobago. Geoforum, 17(3-4): 325-338.

Auty R.M. (ed.), 2001. Resource abundance and economic development. Oxford: Oxford University Press.

Badeeb R.A., Lean H.H., Clark J., 2017. The evolution of the natural resource curse thesis: A critical literature survey. Resources Policy, 51: 123-134.

Baltagi B.H., 1995. Econometric analysis of panel data (vol. 2). Chichester: Wiley.

Barajas M.A., Chami M.R., Yousefi M.R., 2013. The finance and growth nexus re-examined: Do all countries benefit equally? IMF Working Paper No. 13-130, International Monetary Fund.

Beck T., 2011. Finance and Oil: Is there a resource curse in financial development? Discussion Paper, 2011-004, Tilburg University, Center for Economic Research.

Bhattacharyya S., Collier P., 2013. Public capital in resource rich economies: Is there a curse? Oxford Economic Papers, 66(1): 1-24.

Bhattacharyya S., Hodler R., 2010. Natural resources, democracy and corruption. European Economic Review, 54(4): 608-621.

Birdsall N., Pinckney T., Sabot R., 2001. Natural resources, human capital and growth. In: Auty R. (ed.), Resource abundance and economic growth. Oxford: Oxford University Press, pp. 57-75.

Boschini A., Pettersson J., Roine J., 2013. The resource curse and its potential reversal. World Development, 43: 19-41.
Bravo-Ortega C., De Gregorio J., 2005. The relative richness of the poor? Natural resources, human capital and economic growth. Policy Research Working Paper No. 3484. Washington, DC: The World Bank.

Brunnschweiler C.N., 2008. Cursing the blessings? Natural resource abundance, institutions, and economic growth. World development, 36(3): 399-419.

Bulte E.H., Damania R., Deacon R.T., 2005. Resource intensity, institutions, and development. World development, 33(7): 1029-1044.

Byerlee D., 1974. Rural-urban migration in Africa: Theory, policy and research implications. The International Migration Review, 8(4): 543-566.

Collier P., 2010. The plundered planet: Why we must - and how we can-manage nature for global prosperity. New York, NY: Oxford University Press.

Collier P., Hoeffler A., 2005. Resource rents, governance, and conflict. Journal of conflict resolution, 49(4): 625-633.

Collier P., Hoeffler A., 2009. Testing the neocon agenda: democracy in resource-rich societies. European Economic Review, 53(3): 293-308.

Coolidge J., Rose-Ackerman S., 1999. High-level rent-seeking and corruption in African regimes: Theory and cases. Policy Research Working Paper. Washington, DC: The World Bank.

Corden W.M., 1984. Booming sector and Dutch disease economics: survey and consolidation. Oxford Economic Papers, 36(3): 359-380.

Corden W.M., Neary J.P., 1982. Booming sector and de-industrialisation in a small open economy. The Economic Journal, 92(368): 825-848.

Daniele V., 2011. Natural Resources and the 'quality' of economic development. The Journal of Development Studies, 47(4): 545-573.

Davis G.A., Tilton J.E., 2005. The resource curse. Natural Resources Forum, 29(3): 233-242.

Dietz S., Neumayer E., De Soysa I., 2007. Corruption, the resource curse and genuine saving. Environment and Development Economics, 12(1): 33-53.

Djella A., Cembalo L., Furno M., Caracciolo F., 2019. Is oil export a curse in developing economies? Evidence of paradox of plenty on food dependency. New Medit, 18(4): 51-63.

Duranton G., 2015. Growing through cities in developing countries. The World Bank Research Observer, 30(1): 39-73.

Englebert P., 2002. State legitimacy and development in Africa. Boulder, CO: Lynne Rienner Publishers. 
Frankel J.A., 2010. The natural resource curse: $A$ survey. NBER Working Paper No. 15836. National Bureau of Economic Research.

Gollin D., Jedwab R., Vollrath D., 2013. Urbanization with and without Structural Transformation. Mimeograph, George Washington University.

Gylfason T., 2001a. Nature, power and growth. Scottish Journal of Political Economy, 48(5): 558-588.

Gylfason T., 2001b. Natural resources, education, and economic development. European Economic Review, 45(4): 847-859.

Henderson V., 2002. Urbanization in developing countries. The World Bank Research Observer, 17(1): 89-112.

Henderson V., 2010. Cities and development. Journal of Regional Science, 50(1): 515-540.

Humphreys M., Sachs J., Stiglitz J.E. (eds.), 2007. Escaping the resource curse. New York: Columbia University Press.

Kalkuhl M., von Braun J., Torero M., 2016. Volatile and extreme food prices, food security, and policy: an overview. In: Food price volatility and its implications for food security and policy. Cham: Springer, pp. 3-31.

Iimi A., 2006. Did Botswana Escape from the Resource Curse? IMF Working Paper No. 06-138, International Monetary Fund.

Isham J., Woolcock M., Pritchett L., Busby G., 2005. The varieties of resource experience: natural resource export structures and the political economy of economic growth. The World Bank Economic Review, 19(2): 141-174.

Kaufmann D., Vicente P.C., 2011. Legal corruption. Economics \& Politics, 23(2): 195-219.

Lederman D., Maloney W.F., 2008. In search of the missing resource curse. Economía, 9(1): 1-56.

Manzano O., Rigobon R., 2001. Resource curse or debt overhang? NBER Working Paper No. 8390. National Bureau of Economic Research.

Mehlum H., Moene K., Torvik R., 2006. Institutions and the resource curse. The Economic Journal, 116(508): 1-20.

Michaels G., Rauch F., Redding S.J., 2012. Urbanization and structural transformation. Quarterly Journal of Economics, 127(2): 535-586.

Papyrakis E., Gerlagh R., 2003. Natural resources: A blessing or a curse? Working Paper No. 2003.8. Fondazione Eni Enrico Mattei.

Papyrakis E., Gerlagh R., 2004. The resource curse hypothesis and its transmission channels. Journal of Comparative Economics, 32(1): 181-193.
Papyrakis E., Gerlagh R., 2007. Resource abundance and economic growth in the United States. European Economic Review, 51(4): 1011-1039.

Robinson J.A., Torvik R., Verdier T., 2006. Political foundations of the resource curse. Journal of Development Economics, 79(2): 447-468.

Ross M.L., 2001. Does oil hinder democracy? World politics, 53(3): 325-361.

Sachs J.D., Warner A.M., 1995. Natural resource abundance and economic growth. NBER Working Paper No. 5398. National Bureau of Economic Research.

Sachs J.D., Warner A.M., 1997. Sources of slow growth in African economies. Journal of African Economies, 6(3): 335-376.

Sachs J.D., Warner A.M., 1999. The big push, natural resource booms and growth. Journal of Development Economics, 59(1): 43-76.

Sachs J.D., Warner A.M., 2001. The curse of natural resources. European Economic Review, 45(4): 827-838.

Sargan J.D., 1958. The estimation of economic relationships using instrumental variables. Econometrica: Journal of the Econometric Society, 26(3): 393-415.

Sarraf M., Jiwanji M., 2001. Beating the resource curse: The case of Botswana. Environment Department Working Paper No. 83. Washington, DC: The World Bank.

Stijns J.P.C., 2005. Natural resource abundance and economic growth revisited. Resources Policy, 30(2): 107-130.

Tchamda C., Bricas N., 2015. Les villes d'Afrique subsaharienne sont-elles si dépendantes aux importations alimentaires? Question de développement, 27.

Torres N., Afonso Ó., Soares I., 2013. A survey of literature on the resource curse: critical analysis of the main explanations, empirical tests and resource proxies. CEF.UP Working Paper No. 1302. Universidade do Porto, Faculdade de Economia do Porto.

Van der Ploeg F., 2011. Natural resources: Curse or blessing? Journal of Economic Literature, 49(2): 366-420.

World Bank, 2009. World Development Report 2009: Reshaping Economic Geography. Washington, DC: The World Bank.

World Bank, 2011. The Changing Wealth of Nations. Measuring Sustainable Development in the New Millennium. Washington, DC: The World Bank.

Zagozina M., 2014. The resource curse paradox: natural resources and economic development in the former Soviet countries. Master's Thesis, University of Helsinki, Department of Forest Sciences. 
